\title{
Surface water as source in the spread of cucumber green mottle mosaic virus
}

\author{
H. J. M. van Dorst
}

Glasshouse Crops Research Station, P.O. Box 8, 2670 AA Naaldwijk, Netherlands

Received 4 February 1988; accepted 14 April 1988

Key words: cucumber green mottle mosaic virus, virus infection, Cucumis sativus L., surface water, virus transmission

\begin{abstract}
Surface water used for sprinkling irrigation of cucumber plants (Cucumis sativus $\mathrm{L}$.) appeared to be an important source of infection with cucumber green mottle mosaic virus. In glasshouse conglomerates where the infections with this virus were generally observed in cucumber crops, the surface water was contaminated during the greater part of the year. The first virus was found in spring and its concentration reached a maximum in June-July. In August, when at the end of the cropping period the plants are hardly sprinkled anymore, the concentration was low. In September, when the crop is removed and the soil leached, the concentration rose again.

The virus was also found in seepage from dumping sites of unsold cucumber fruits and crop debris, in packing containers used for the harvest of fruits and for the transport of young plants, and in manure of cows fed with unsold, virus-infected fruits. In tap and well water the virus was never found.
\end{abstract}

\section{Introduction}

Cucumber green mottle mosaic virus (CGMMV) is by far the most important virus disease in cucumber in the Netherlands. The virus survives in the soil and is transmitted with infected cucumber seeds (van Koot \& van Dorst, 1959; Hollings et al., 1975). It may be taken up by the plants via the roots from infected water (Paludan, 1985).

Soil disinfection and heat treatment of the seed (Fletcher et al., 1969) which excluded transmission via seed, reduced the early disease incidence in commercial practice, but did not annihilate the incidence of the disease. be:

This may indicate that the virus may spread from unknown sources. They may

- surface water, especially since the disease occurred much more frequently in re- 
gions where surface water was used for sprinkling, notably near waste heaps and dumping sites of cucumber material, than in regions where well water was applied;

- packing containers used for the harvest of cucumber fruits as well as for transporting young plants;

- manure of cattle fed with virus-diseased fruits.

The significance of these potential sources of infection was studied and the results are presented below.

\section{Materials and methods}

\section{Test plants}

Cucumber (Cucumis sativus L. cv. Sporu) was used as test plant, grown in sterilized potting soil in glasshouses at $20-25{ }^{\circ} \mathrm{C}$ and a relative humidity of $60-80 \%$. In winter, supplementary light was applied with HPL lamps of $40 \mathrm{~W} \mathrm{~m}^{-2}$. The inoculations were made on the cotyledons and the first true leaf of ca $10 \mathrm{~cm}$ length, using carborundum (500 mesh) and a wad of cotton wool. After inoculation, the leaves were rinsed with tap water. The plants were checked for virus symptoms during 6-7 weeks after inoculation. Three weeks after inoculation a fertilizer was applied consisting of $\mathrm{N}, \mathrm{P}_{2} \mathrm{O}_{5}, \mathrm{~K}_{2} \mathrm{O}$ and $\mathrm{MgO}$ in the ratio 15:5:16:6, in a quantity of $0.7 \mathrm{~g}$ to each 0.751 pot. In order to prevent virus transmission by contact, the plants were supported with a bamboo cane. In all experiments, tap water was used for watering.

\section{Sampling and sampled objects}

Every fortnight, water samples were taken from each of the locations (A-J) to be sampled. The locations A-E are in a region where the disease occurred early in the season and was widespread and where the crops were sprinkled with surface water. Sampling was carried out over a period of 25 months. The locations F-I are in a region where the disease occurred to a limited extent and the crops were sprinkled mostly with well water. Samples from these locations were studied for 10 months.

Sample at location A was taken at the side of a ditch, samples at locations B-G at $1 \mathrm{~m}$ off the side of a ditch. If during the winter months the water was covered with ice, the samples were taken from under the ice. In the first 10 months of this experiment, each sample was inoculated on 10 test plants. In the 15 following months, for each sample 100 test plants were used, with the exception of the samples from the dumping site, to increase the chance to detect the virus. To each test plant ca $3 \mathrm{ml}$ was applied.

Samples were taken at the following locations:

A. A ditch $0.3 \mathrm{~m}$ deep and $2 \mathrm{~m}$ wide with poor circulation, running along a dumping site of unsold horticultural products which were deposited there between May and September.

B. Seven ditches $0.5 \mathrm{~m}$ deep and $2 \mathrm{~m}$ wide with little circulation into which drainage water was discharged via drainage pipes from glasshouses with plants infected early in the season. 
C. Four sampling sites in a waterway $1.2 \mathrm{~m}$ deep and $8 \mathrm{~m}$ wide with ample circulation into which drainage water was discharged from glasshouses where the disease occurred already early in the season.

D. Four waterways ca $1.7 \mathrm{~m}$ deep and $10 \mathrm{~m}$ wide of good circulation into which drainage water was discharged from only a limited number of glasshouses with plants infected early in the season.

E. Three waterways ca $2.5 \mathrm{~m}$ deep and $14 \mathrm{~m}$ wide with very good circulation into which drainage water was discharged from only some glasshouses with early-infected crops.

F. A ditch ca $0.7 \mathrm{~m}$ deep and $4 \mathrm{~m}$ wide with ample circulation into which drainage water was discharged from glasshouses with crops infected early in the season.

G. As F, but with drainage water from glasshouses with crops which were not infected until late in the season.

H. Drainage water from 3 nurseries where the virus did not occur.

I. Well water from a depth of $35 \mathrm{~m}$ on 4 nurseries.

J. Seepage from 2 dump sites which were deliberately made with 40 and 110 diseased plants, respectively. In dry periods the heaps were wetted with tap water to collect seepage regularly.

Furthermore samples were taken from:

$\mathrm{K}$. The paddings of 10 cucumber trays which were used for 8 months on early infected nurseries. Each padding, consisting of a $1.5 \mathrm{~cm}$ thick layer of plastic foam for the prevention of fruit damage, was immersed in 11 of distilled water for $24 \mathrm{~h}$ and then wrung out. This water was used as inoculum.

L. Hard polyethylene picking trays from 2 nurseries with crops infected by the disease, one early ( 3 trays used during 6 months), the other late in the season ( 2 trays used during 8 months). After removal of coarse contaminations, the trays were rubbed off with moist wads both on the inside and on the outside. The wads of each tray were washed out in $25 \mathrm{ml}$ of distilled water which was subsequently used as inoculum.

M. Cow manure. To answer the question whether the virus could survive a passage through cows, $20 \mathrm{~kg}$ of diseased cucumber fruits was fed to a cow in addition to her daily meal, and another cow was given $13 \mathrm{~kg}$ virus-free cucumber fruits. During the following 5 days the solid manure was collected, diluted with $15 \%$ distilled water and filtered through cheese-cloth. The filtrate, on average $180 \mathrm{ml}$ per animal, was used as inoculum. Furthermore, cucumber seeds were collected from the manure and after 2 months their germinative capacity determined.

In all inoculations, tap water was used as control treatment.

\section{Infection via sprinkling}

In order to determine whether cucumber plants can be infected by wetting the leaves with virus-contaminated water by using either a watering can or a sprinkling system, different virus dilutions were applied. Apart from fresh press sap from young virus-infected cucumber leaves, also press sap was used which had been stored for a year at $-20{ }^{\circ} \mathrm{C}$. In both treatments, tap water was used for the dilutions. In addi- 
tion, plants were inoculated with different sap dilutions in order to determine the infectivity of each dilution. Watering with a watering can and inoculations were carried out during the second true-leaf stage. For each 100 plants watered with a finerosed watering can, 101 water and no carborundum was used. After the first virus symptoms occurred, the remaining plants were checked for another 5 weeks.

\section{* Infected plants}

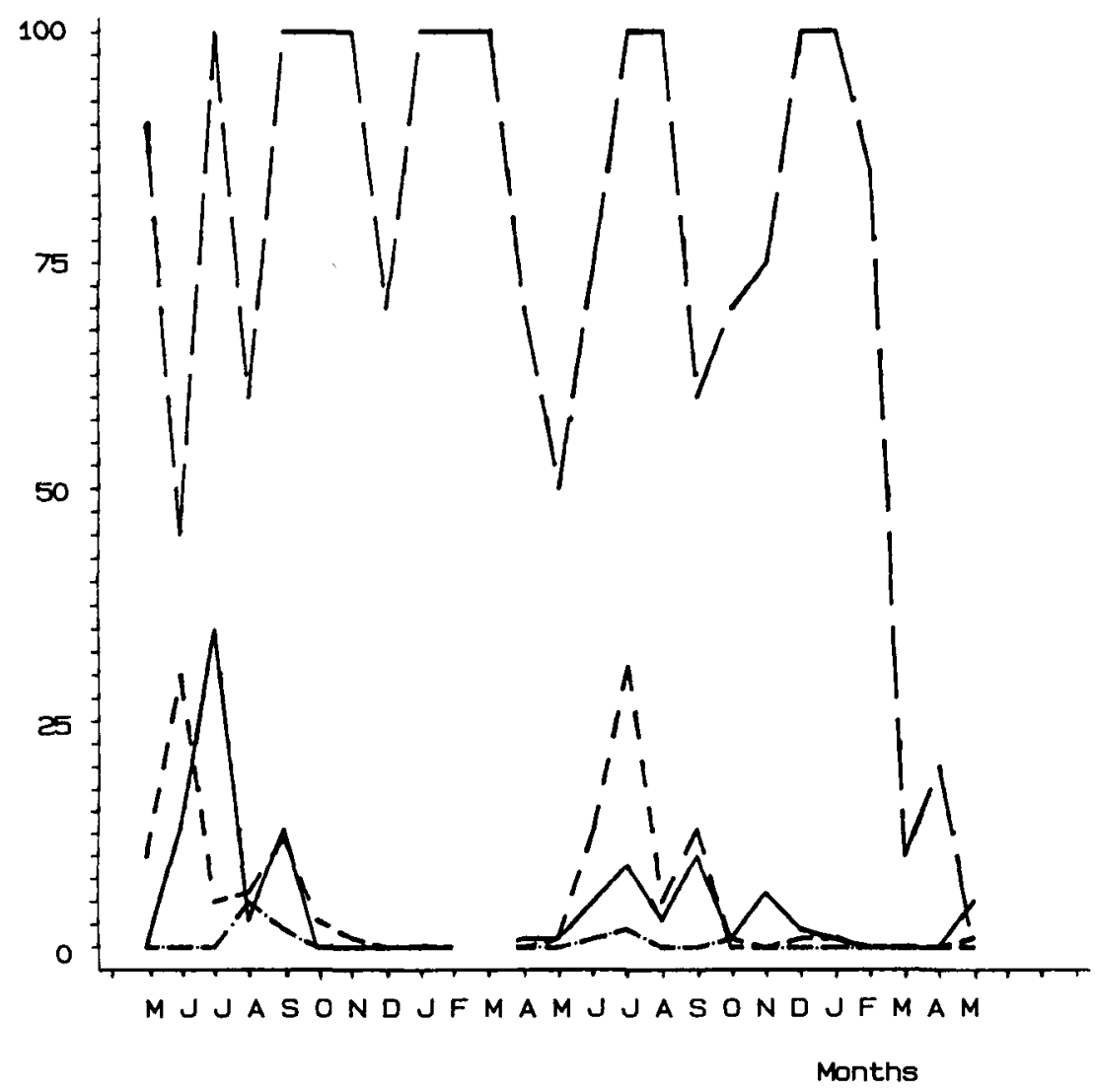

Fig. 1. Percentage of cucumber plants infected with cucumber green mottle mosaic virus obtained after inoculations with samples of surface water for 2 years in a region where the virus was widespread and occurred early in the season, and where the crops were sprinkled with surface water. - - (A) a ditch near a dumping site: - - - - (B) average of samples from 7 ditches, $0.5 \mathrm{~m}$ deep and $2 \mathrm{~m}$ wide into which drainage water was discharged directly; — (C) average of 4 sampling sites in a waterway $1.2 \mathrm{~m}$ deep and $8 \mathrm{~m}$ wide; - . - . - (D) average of 4 waterways $1.7 \mathrm{~m}$ deep and $10 \mathrm{~m}$ wide. 


\section{Results}

\section{Samples of the surface water}

The results of the water samples from the locations A-D and F-G are summarized per month and presented in Figs. 1 and 2, respectively. Except for the winter months, the virus could always be demonstrated in the surface water. The first virus was found in spring and its concentration reached a maximum in June-July. In JulyAugust it dropped whereas in September it rose again. In November a minor peak could be observed on some occasions; subsequently the concentration rapidly decreased. Near the dumping site (A), however, the virus occurred constantly in high concentrations. The concentration of virus measured was low on this location in periods with little or no rainfall.

As the waterways were wider and deeper and especially as they had better circulation, less virus was found. In deep waterways (samples E) with very good circulation, the virus was not demonstrated. Likewise, on nurseries with virus-free plants, virus could not be detected in drainage water (samples H). Neither was it found in well water (samples I).

\section{Virus discharge from waste heaps}

For a long time the virus occurred in the seepage from waste heaps. From the first heap it was discharged for 8 months and from the second during 9 months. In rainy periods the concentration was highest.

\section{* Infected plants}

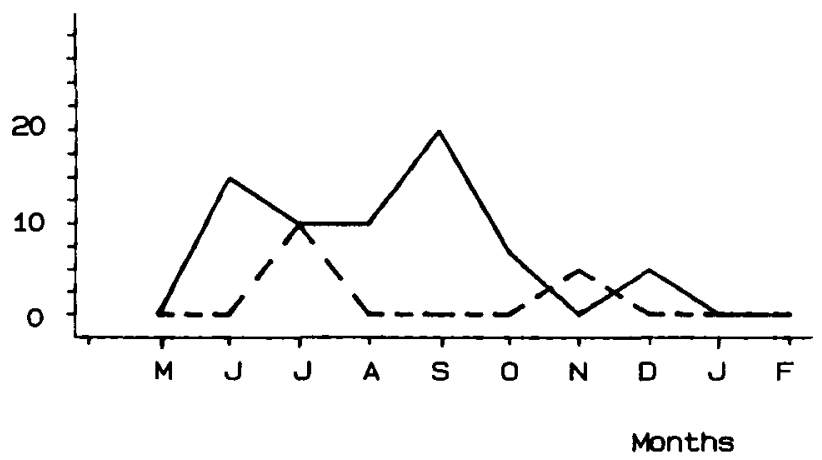

Fig. 2. Percentage of cucumber plants infected with cucumber green mottle mosaic virus obtained after inoculation with samples of surface water during 10 months in a region where the virus was not widespread and where the crops were mostly sprinkled with well water. $-(\mathrm{F})$ a ditch, $0.7 \mathrm{~m}$ deep and $4 \mathrm{~m}$ wide, into which drainage water was discharged from crops infected early with the virus; - - - $(\mathrm{H})$ a ditch, $0.7 \mathrm{~m}$ deep and $4 \mathrm{~m}$ wide, into which drainage water was discharged from crop infected late with the virus. 


\section{Packing material}

In the first experiment, 9 of the 10 paddings of cucumber trays (see $\mathrm{K}$ ) could be demonstrated to carry the CGMMV. One to 4 of the 10 plants used to test a padding attracted infection. In the second experiment (see L) the virus could not be found on the outside of either of the 2 trays from the nursery with the late virus infection in the crop, whereas it could be demonstrated on the inside of only one of them ( 2 of the 10 test plants became diseased). Two of the 3 trays from the nursery with an early and strong virus infection were found to be CGMMV-contaminated on the outside ( 1 of the 10 test plants became diseased) and all of them on the inside (on average 4 of the 10 test plants became diseased).

\section{Cow manure}

Table 1 indicates that during the first 3 days after feeding the virus was recovered in the manure. On the first and the second day, high concentrations were found which subsequently declined. On all 5 days, cucumber seeds were found back, most of them on the second and third day. The germinative capacity decreased from $100 \%$ after 1 day to $90 \%$ after 5 days.

Table 1 . Incidence of infected plants $(\%)$ as influenced by inoculation with filtrate from cows fed with virus-diseased and virus-free cucumber fruits. Manure collected 1, 2, 3, 4 and 5 days after feeding.

\begin{tabular}{|c|c|c|c|c|c|}
\hline Feeding & 1 & 2 & 3 & 4 & 5 \\
\hline $20 \mathrm{~kg}$ virus-diseased cucumbers & 100 & 100 & 1 & 0 & 0 \\
\hline $13 \mathrm{~kg}$ virus-free cucumbers & 0 & 0 & 0 & 0 & 0 \\
\hline
\end{tabular}

Table 2. Percentage of cucumber plants infected with cucumber green mottle mosaic virus after watering once with a watering can or inoculating with dilutions of fresh and stored ( 1 year at $20^{\circ} \mathrm{C}$ ) sap pressed from young infected cucumber leaves.

\begin{tabular}{|c|c|c|c|c|}
\hline \multirow{2}{*}{$\begin{array}{l}\text { Dilution } \\
\text { press sap }\end{array}$} & \multicolumn{2}{|c|}{ Fresh press sap } & \multicolumn{2}{|c|}{ Stored press sap } \\
\hline & watering & inoculating & watering & inoculating \\
\hline $1: 10^{3}$ & 47 & 100 & 38 & 100 \\
\hline $1: 10^{4}$ & 18 & 100 & 6 & 100 \\
\hline $1: 10^{5}$ & 2 & 92 & 1 & 86 \\
\hline $1: 10^{6}$ & 0 & 52 & 0 & 48 \\
\hline $1: 10^{7}$ & 0 & 11 & 0 & 6 \\
\hline $1: 10^{8}$ & 0 & 2 & 0 & 0 \\
\hline $1: 10^{9}$ & 0 & 0 & 0 & 0 \\
\hline Tap water & 0 & 0 & 0 & 0 \\
\hline
\end{tabular}

Numbers of plants used:

- Watering: $10^{3}-10^{5}: 100 ; 10^{6}: 250 ; 10^{7}-10^{8}: 500 ; 10^{9}: 1000 ;$ tap water: 100 .

- Inoculating: $\left.10^{3}-10^{6}: 50 ; 10^{7}-10^{4}: 100\right)$ t tap water: 50 . 


\section{Watering with infected sprinkling water}

The plants are readily infected with contaminated water when sprinkled with a watering can (Table 2). Sap from infected plants diluted $1: 10^{5}$ resulted in $1-2 \%$ diseased plants when sprinkled and 86-92\% diseased plants when inoculated.

\section{Discussion}

The experiments explicitly demonstrate that CGMMV may often be present in high concentrations in the surface water contaminated by infected drainage water from the glasshouses and seepage from a dumping site. Furthermore it was demonstrated that the use of contaminated water may easily result in infections.

In recent years, the presence of other virus diseases in surface water has been determined as well (Tomlinson et al., 1983; Tomlinson \& Faithfull, 1984; Koenig, 1986).

The relatively rapid increase of the virus concentration in the surface water in spring is probably caused by the fast-growing number of diseased plants as a consequence of the many activities in the crop such as pruning and harvesting. The virus may be released from dying roots and end up in the drainage water during sprinkling of the crops. In August the plants are practically no longer sprinkled, because the crop is coming to an end. Consequently, lower concentrations are found then. In this month and in September the majority of the crops are cleared. Then the soils are leached, which explains the increasing virus concentration in the surface water.

In centres where the virus occurred hardly or not at all in the crops, it was nonetheless demonstrated in ditches albeit in lower concentrations than in centres where the disease was widespread. On many nurseries, virus-free well water was used for sprinkling; this excludes the sprinkling water as source of infection. Those growers who do not have well water at their disposal have to water with contaminated surface water.

As waterways are deeper and have better circulation, the virus is carried off more quickly and consequently the concentration will be lower and the transmission factor smaller.

When plants were sprinkled with $1: 10^{5}$ diluted sap from infected plants, only 1$2 \%$ of them became infected. Inoculation of this sap resulted in $86-92 \%$ of the plants being infected. The latter infection level was also obtained with water from the dumping site (location A). Inoculation of 100 plants with a $1: 10^{9}$ dilution of this sap did not result in diseased plants. Probably, infections would have been found if a much larger number of test plants was used.

In winter, when inoculations did not reveal any virus in the water samples (Fig. 1), the concentrations must have been similar or lower than sap diluted 1:10\%. The level of detection may have been higher when the samples were concentrated. In the glasshouse centres concerned, where several millions of cucumber plants are planted out, the first infections begin on only a few scattered plants. If then the plants are sprinkled regularly with surface water, the risks of infection rapidly increase. In experiments of the scope of the present research, infections at these low 


\section{H. J. M. VAN DORST}

concentrations cannot be demonstrated anymore.

The infectivity of sap pressed from young leaves stored for a year at $-20{ }^{\circ} \mathrm{C}$ hardly decreases. This high resistance of the virus for low temperatures can explain that the seepage from the dumping site at location A (Fig. 1) is still infectious after the winter.

The presence of dumping sites for unsold fruits and for crops cleared from the glasshouses in the immediate neighbourhood of ditches and other waterways may be an important source of infection of the surface water for 9 months, particularly during rainy periods. If dumping sites and waste heaps are located further away from ditches and waterways, this risk of contamination of the surface water will be smaller. Several times during the collection of the water samples, drainage water could be collected directly from the drainage pipes and shown to contain virus. The assumption seems therefore plausible that the surface water may also be contaminated by drainage water discharged from glasshouses with infected crops. Well and tap water, in which the virus could not be detected, are safe sources for plant sprinkling.

Cucumber seed in manure retains its germinative capacity, implying that storage of cow manure may also be a source of infection. CGMMV could be demonstrated in packing containers and in cow manure, which makes them probable sources of infection. The sides of the packing containers may have become infected during harvest and transport of infected fruits. In the past, also young cucumber plants ready for planting out were transported in these containers. During transport the leaves might touch the infected sides, resulting in the possibility of an early infection. Cow manure, mixed with the soil, was often used in the past as fertilization of cucumber. In view of the fact that cows were fed with cucumber fruits in periods of over-production and that the virus readily survives in soil and subsequently may infect the plants, cow manure may have acted as a source of infection. Due to changes in commercial practice, propagation nurseries use separate containers for the transport of plants. Since cow manure is also no longer used in the Netherlands in cucumber cultivation, neither containers nor manure is a possible source of infection anymore.

\section{Acknowledgements}

The author wishes to thank Mrs M. Groen-van de Berg and Mrs L. Knijnenburgvan der Lans for their accurate assistance; Mr B. van Schie at Honselersdijk for placing at his disposal 2 cows for the manure research; De Ruiter Seeds at Bleiswijk for providing a large quantity of cucumber seed; Dr G. Weststeijn and Dr N. A. M. van Steekelenburg for critically reading the manuscript; and $\mathrm{Mr} \mathrm{W}$. A. van Winden for the English translation.

\section{References}

Fletcher. J. T.. A. J. George \& D. E. Green. 1969. Cucumber green mottle mosaic virus, its effect on yield and its control in the Lea Valley. England. Plant Pathology 18: 16-22.

Hollings, M. . Y. Komuro \& H. Tochihara, 1975. Cucumber green mottle mosaic virus. CMI/AAB Descriptions of Plant Viruses No 154. 
Koenig, R., 1986. Plant viruses in rivers and lakes. Advances in virus research 31: 321-333.

Koot, Y. van, \& H. J. M. van Dorst, 1959. Virusziekten van de komkommer in Nederland. Tijdschrift over Planteziekten 65: 257-271.

Paludan, N., 1985. Spread of viruses by recirculated solutions in soilless cultures. Danish Journal of Plant and Soil Science 89; 467-474.

Tomlinson, J. A., E. M. Faithfull, M. J. W. Webb, R. S. S. Fraser \& N. D. Seeley, 1983. Chenopodium necrosis: a distinctive strain of tobacco necrosis virus isolated from riverwater. Annals of Applied Biology 102: 135-147.

Tomlinson, J. A. \& E. M. Faithfull, 1984. Studies on the occurrence of tomato bushy stunt virus in English rivers. Annals of Applied Biology 104: 485-495. 